\title{
Kolorektal Kanserlerin Tanı ve Prognostik Takibinde Eski ve Yeni Serum Biyobelirteçleri: Sistematik İnceleme ve Meta-Analiz
}

\author{
Muhammed Zübeyr ÜÇÜNCÜ*
}

\section{$\ddot{O} \mathbf{z}$}

$\mathrm{Bu}$ mini derleme ve sistematik meta analizde kolorektal karsinomun tanısında ya da prognozunda araştırılmış olan bazı biyobelirteçlerin irdelenmesi amaçlanmıştır. Yapılan analizler karsinoembriyonik antijenin (CEA) kolorektal karsinom tanısında orta duyarlılık ve yüksek özgüllük değerlerinde olduğunu, ancak kolorektal kanseri yakalamakta yetersiz olduğunu, prognozun belirlenmesinde kullanılabileceğini göstermektedir. Karbonhidrat Antijeni 19-9'un (CA19-9) tek başına kolorektal karsinom taramasında, tanısında, prognozunun belirlenmesinde veya nükslerin yakalanmasında kullanılamayacă̆ı, diğer belirteçlerle birlikte kullanıldığında bilgi sağlayıcı olabileceği görülmüştür. Kanser Antijeni 242'nin (CA242) kolorektal karsinom tanısında ve prognozunun belirlenmesinde özellikle CEA ve/veya CA19-9 gibi farklı tümör belirteçleriyle birlikte kullanılabileceği gösterilmiştir. C-reaktif Proteininin (CRP) inflamasyon için spesifik bir belirteç olduğu, kolorektal karsinom gelişme riskini belirlemede, tanı koymada ve prognozu anlamada kullanılabileceğini ancak kolorektal karsinoma özgül bir belirteç olmadığı görülmüştür. Vasküler Endotelyal Büyüme Faktörü (VEGF) ile kolorektal karsinomun ilişkili olduğu ve VEGF'in bu olgularda tanıda ve prognozu belirlemede belirteç olarak kullanılabileceği ortaya konulmuştur. MicroRNA’ların kolorektal karsinom taramasında, tanısında ve prognozunun belirlenmesinde kullanılabileceği gösterilmiştir. Diğer belirteçlerden Kanser Antijeni 50 (CA-50), İnsülin Benzeri Büyüme Faktörü Bağlanma Proteini 3 (IGFBP-3), İnsülin Benzeri Büyüme Faktörü-1’i (IGF-1), Kanser Antijeni 72-4’ün (CA72-4), Tümör İlişkili Glikoprotein-72 (TAG-72), P53, Kanser Antijeni 125’in (CA125), c-erbB-2 proteini, Doku Metalloproteinaz İnhibitörü-1'in (TIMP-1) ve Pirüvat Kinaz İzoenzimi M2'nin (M2-PK) kolorektal karsinomda sınırlı oranda kullanılabileceği görülmüştür.

Derleme Makale (Review Article)

Geliş / Received: 18.07.2019 \& Kabul / Accepted: 02.10.2019

${ }^{*}$ Sorumlu Yazar. Dr. Öğr. Üyesi, İstanbul Gelişim Üniversitesi, Sağllk Bilimleri Enstitüsü, İstanbul, Türkiye, E-posta: muahmmeducuncu@gmail.com

ORCID IID https://orcid.org/0000-0003-4638-1059 
Kolorektal karsinomların taranmasında, tanısında, izleminde ve prognozunun belirlenmesinde ileri derecede güvenilir bir biyobelirteç henüz belirlenebilmiş değildir. Ancak belirteçlerin araştırılması değişik duyarlılık ve özgüllük oranlarına rağmen klinisyen ve hasta için büyük fayda sağlamaktadır. Özellikle bazı belirteçlerin kombine kullanımının bu olgularda önemli yarar sağladı̆̆g görülmüştür.

Anahtar sözcükler: Kolorektal karsinom, CEA, CA19-9, CA242, microRNA, tanı, prognostik faktör.

\title{
Former and Recent Serum Biomarkers in Diagnosis and Prognostic Follow-up of Colorectal Cancers: Systematic Review and Meta-Analysis
}

\begin{abstract}
This mini review and systematic meta-analysis aimed to investigate some biomarkers that have been investigated in the diagnosis or prognosis of colorectal carcinoma. Analyzes show that carcinoembryonic antigen (CEA) has moderate sensitivity and high specificity in the diagnosis of colorectal carcinoma, but it is insufficient to detect colorectal cancer and can be used to determine prognosis. Carbohydrate Antigen 19-9 (CA19-9) alone cannot be used for colorectal carcinoma screening, diagnosis, prognosis or detection of relapses, and it can be used when used in conjunction with other markers. It has been shown that Cancer Antigen 242 (CA242) can be used in combination with different tumor markers such as CEA and / or CA19-9 in the diagnosis and prognosis of colorectal carcinoma. C-reactive protein (CRP) is a specific marker for inflammation, it can be used to determine the risk of developing colorectal carcinoma, to diagnose and to understand prognosis, but it is not a specific marker of colorectal carcinoma. Vascular Endothelial Growth Factor (VEGF) is associated with colorectal carcinoma and VEGF can be used as a marker in the diagnosis and prognosis of these cases. It has been shown that microRNAs can be used for colorectal carcinoma screening, diagnosis and prognosis. Other markers include Cancer Antigen 50 (CA-50), Insulin Like Growth Factor Binding Protein 3 (IGFBP-3), Insulin Like Growth Factor-1 (IGF-1), Cancer Antigen 72-4 (CA72-4). Tumor Related Glycoprotein-72 (TAG-72), P53, Cancer Antigen 125 (CA125), c-erbB-2 protein, Tissue Metalloproteinase Inhibitor-1 (TIMP-1) and Pyruvate Kinase Isoenzyme M2 (M2-PK) have been shown to be limited in colorectal carcinoma. A highly reliable biomarker for screening, diagnosis, follow-up and prognosis of colorectal carcinomas has not yet been established. However, the search for markers is of great benefit to the clinician and the patient, despite varying sensitivity and specificity rates. In particular, the combined use of some markers has been shown to provide significant benefit in these cases.
\end{abstract}

Keywords: Colorectal carcinoma, CEA, Ca19-9, CA 242, Micro RNA, prognostic factor. 


\section{Giriş}

Kolorektal karsinomlar en sık görülen kanser türlerinden biridir. Dünyada yılda yaklaşık yarım milyon yeni kolorektal karsinom olgusu rapor edilmektedir. $\mathrm{Bu}$ olgularda yüksek morbidite ve mortalite oranları bildirilmektedir. Kolorektal karsinom ileri yaşlarda ve yeme alışkanlıklarıyla da ilişkili olarak sosyo-ekonomik olarak gelişmiş toplumlarda daha sık görülmektedir. Bu kanserlerin erken tanısının ve prognozunun belirlenebilmesi mortalite ve morbitidenin azaltılmasına, iyi bir survive için kritik öneme sahiptiri-3.

Kolorektal karsinom taramasında amaç Dukes A ve B evrelerindeki hastalı̆̆ saptayabilmektir. Çünkü daha ileri evrelerde saptanan malignitelerin tedavi edilebilmeleri çok daha düşük olasılıklıdır4. Kolorektal karsinom taraması için US Preventive Services Task Force, American Cancer Society, US Multi-Society Task Force on Colorectal Cancer, and American College of Radiology American College of Physicians ve American College of Physicians gibi kuruluşların hazırladıkları kılavuzlar bulunmaktadır3-5. Bu kılavuzlara göre tarama için kolonoskopi ve bilgisayarlı tomografili kolonografi gibi görüntüleme yöntemleri; gaitada gizli kan testi ve fekal immünokimyasal testler gibi gaita testleri ve kanser riskini arttıran genetik sendromların araştırıldığı genetik bazlı testleri önermektedir3,5,6. Ancak girişimsel işlemlerin haricinde doğru sonuç verebilen, hızlı ve pratik testlere ihtiyaç duyulmaktadır. Kolorektal karsinom taraması için henüz kabul edilebilir yükseklikte duyarlılık ve özgüllük oranlarına ideal bir teste ulaşlamamıştır. Serumda tespit edilebilen birçok tümör belirteci üzerinde uzun yıllardır çeşitli çalışmalar yapılmaktadır ${ }^{2,5}$.

Çalışmamızda kolorektal karsinomun tanısı ya da prognozunda kullanılabilecek ideal bir beliteç tespitine yönelik eski ve yeni çalışmaların sonuçlarının irdelenmesi amaçlanmıştır.

\section{Kolorektal Karsinom Tanısında Araştırılan Bazı Biyobelirteçlere Ait Rapor Edilmiş Duyarıılı ve Özgüllük Oranları Aralıkları}

Kolorektal karsinom tanısında araştırılan bazı biyobelirteçlere ait rapor edilmiş duyarlılık ve özgüllük oranları aralıkları Tablo 1'de gösterilmiştir. 
Tablo 1. Bazı belirteçlere ait yapılan araştırmalarda kolorektal karsinom tanısı için bildirilen duyarlılık ve özgüllük oranları aralıkları1,7,8.

\begin{tabular}{|c|c|c|}
\hline Biyobelirteçler & Duyarlılık (\%) & Özgüllüik (\%) \\
\hline Karsinoembriyonik antijen (CEA) & $44,8-47,4$ & $88,2-90,2$ \\
\hline Karbonhidrat Antijeni 19-9 (CA19-9) & $28,3-31,8$ & $91,5-94,0$ \\
\hline Kanser Antijeni 242 (CA242) & $36,8-41,3$ & $86,4-90,1$ \\
\hline C-reaktif Proteininin (CRP) & $30,2-35,0$ & $72,2-75,4$ \\
\hline Vasküler Endotelyal Büyüme Faktörü (VEGF) & $52,5-59,9$ & $76,0-84,7$ \\
\hline Micro RNA & $58,8-59,3$ & $84,8-85,6$ \\
\hline Kanser Antijeni 50 (CA-50) & $34,3-43,1$ & $74,3-80,9$ \\
\hline $\begin{array}{l}\text { İnsülin Benzeri Büyüme Faktörü Bağlanma } \\
\text { Proteini } 3 \text { (IGFBP-3) }\end{array}$ & $18,7-21,7$ & $78,0-80,9$ \\
\hline İnsülin Benzeri Büyüme Faktörü-1 (IGF-1) & $20,0-24,2$ & $76,0-79,8$ \\
\hline Kanser Antijeni 72-4'ün (CA72-4) & $27,0-33,0$ & $94,1-97,0$ \\
\hline Tümör İlişkili Glikoprotein-72 (TAG-72) & $38,7-46,8$ & $94,2-97,6$ \\
\hline P53 & $18,8-27,8$ & $96,6-100$ \\
\hline Kanser Antijeni 125’in (CA125) & $14,2-22,4$ & $91,9-97,2$ \\
\hline c-erbB-2 proteini & $24,1-40,9$ & $55,8-70,4$ \\
\hline Doku Metalloproteinaz Ínhibitörü-1 (TIMP-1) & $42,1-48,8$ & $92,5-97,1$ \\
\hline Pirüvat Kinaz İzoenzimi M2 (M2-PK) & $46,0-57,6$ & $84,7-97,7$ \\
\hline
\end{tabular}

Karsinoembriyonik antijen (CEA): CEA, kolorektal kanserler başta olmak üzere gastrointestinal sistem, akciğer, karaciğer, pankreas, meme, over, baş-boyun ve prostat kanserleri ile ilişkisi gösterilmiş olan bir tümör belirtecidir. CEA, 150-30o kDa arasında molekül ağırlığı olan bir glikoproteindir. Kolon, mide, pankreas ve akciğerde bulunan embriyonik endodermal kaynaklı epitel hücreleri tarafından üretilir. Kanserler dışında ülseratif kolit, enterit, divertikülit, pankreatit, peptik ülser, siroz, hepatit ve bazı 
enfeksiyonlar gibi durumlarda da serum düzeylerinde artış görülebilir4,9-11.

Tarama: Fletcher ve ark. ${ }^{11}$ Dukes A ve B evrelerinde CEA' nın kolorektal kanseri saptama konusunda duyarlılı̆̆ının \%36, özgüllüğünün \%87 olduğunu rapor etmişlerdir. Klapdor ve $\operatorname{ark}^{12}$ da CEA' nın kolorektal karsinom taramasında düşük duyarlılıkta olduğunu vurgulamıştır. Duffy ve ark..2,4,13,14 yaptıkları dört farklı meta analiz ve derlemelerde CEA' nın tarama amaçlı olarak kabul edilemeyecek kadar düşük duyarlılık değerine sahip olduğu sonucuna varmışlardır. Bu raporlardan elde edilen veriler CEA' nın kolorektal karsinom için pozitif prediktif değerinin kabul edilemez derecede düşük olduğunu ve sağlıklı bireylerin taramasında düşük değere sahip olduğunu göstermektedir. Kolorektal karsinom taramasında gaitada gizli kan ve endoskopi verileri halen önemini korumaktadır ${ }^{15}$.

Tanı: Tarama konusunda olduğu gibi kolorektal karsinom tanısında da CEA'nın düşük duyarlılık ve özgüllük değerleri bulunmaktadır. Semptomatik kişilerde doğal olarak daha ileri düzeyde hastalık bulunması dolayısıyla asemptomatik kişilere oranla daha yüksek CEA düzeyleri bulunduğu vurgulanmıştır4,11. CEA' nın birçok kanserin yanı sıra kanser dışı bazı hastalıklarda da yükseldiği bilinmektedir. Bu nedenle ayırıcı tanının yapılması gereklidir. Benign hastalıklarda CEA serum düzeyinin $10 \mathrm{ng} / \mathrm{mL}$ ' yi nadiren geçebildiği, bu nedenle de aşırı yüksek CEA düzeylerinin kanserle uyumlu semptomları olan hastada kanser varlığını büyük ölçüde gösterebildiği belirtilmiştir4,9,10.

CEA tanısal duyarlılık oranları \%30-80 aralığında değişmektedir. Duyarlılık oranlarını Wild ve ark. ${ }^{16} \% 44$, Lee ve ark. ${ }^{17} \% 29$, Fernandes ve ark. ${ }^{10} \% 56$, Saito ve ark. ${ }^{18} \% 38$, Marrelli ve ark. ${ }^{19} \% 36$, Dbouk ve ark. ${ }^{20} \% 58$, Chen ve ark..$^{21} \% 41$, Takeda ve ark. ${ }^{22}$ ise \%40 olarak bulmuşlardır. Birbirine yakın olan bu oranların yanı sıra Çoban ve ark. ${ }^{23}$ \%87,5 gibi yüksek bir duyarlılık oranı rapor etmiştir.

CEA’nın tanısal özgüllük oranlarında da değişkenlik görülmekle birlikte oranlar duyarlılık oranlarına göre çok daha yüksektir. Wild ve ark. ${ }^{16} \% 95$, Lee ve ark. ${ }^{17} \% 100$, Fernandes ve ark. ${ }^{10} \% 95$, Saito ve ark. ${ }^{18} \% 95$, Marrelli ve ark. ${ }^{19} \% 91$, Dbouk ve ark. ${ }^{20}$ $\% 88$, Chen ve ark. ${ }^{21} \% 87$, Takeda ve ark. ${ }^{22} \% 96$, Çoban ve ark. ${ }^{23} \% 96,4$ olarak bulmuşlardır. Tüm bu duyarlılık ve özgüllük verileri CEA'nın kolorektal karsinoma nerdeyse özgül olduğunu ancak kolorektal kanseri yakalamakta yetersiz olduğunu göstermektedir. 
Prognoz: CEA kolorektal karsinomların prognozunu belirlemekte de kullanılan bir belirteçtir. Liu ve ark. ${ }^{1}$ yaptıkları geniş meta analizde kolorektal karsinom konulu araştırmalarda en sık incelenen belirtecin CEA olduğunu vurgulamışlardır. Bazı çalışmalar CEA' nın kanserin evresinden bağımsız olarak hastalığın prognozunu belirlemede bilgi sağlayıcı olduğunu bildirmiştir4,9,10. Bununla birlikte evre 2'de prognozun belirlenmesinde kullanılabilir olduğu belirtilmiştir. Bazı çalışmalarda ise hangi hastaların adjuvan kemoterapi alması gerektiğinin belirlenebilmesi için CEA' nın yeni tanı konulan olgularda histopatolojik parametrelerle birlikte değerlendirilmesi gerektiği rapor edilmiştir ${ }^{13,24,25}$. Huo ve ark. ${ }^{26}$, Peltonen ve ark. ${ }^{27}$, Yang ve ark. ${ }^{28}$, Park ve ark. ${ }^{29}$, Louhimo ve ark. ${ }^{30}$ ve Carriquiry ve ark. ${ }^{31}$ düşük riskli yani Dukes B sınıfı veya lenf nodu metastazı olmayan hastalarda CEA' nın prognostik faktör olduğunu rapor etmişlerdir. Ancak Carpelan-Holmström ve ark.32 CEA’nın tek başına prognostik olmadı̆̆ını, CA242 ile değerlendirildiğinde prognostik değeri olduğunu bildirmişlerdir.

Karbonhidrat Antijeni 19-9 (CA19-9): İlk kez insan kolorektal karsinom hücrelerinden izole edilmiş olan CA19-9 36 kilodalton ağırlığında bir glikolipiddir. İnsan A kan grubu antijeninin hapteni ile aynı yapıdadır. Dolaşımdaki müsinin ve bazı kanser dokularının yapısında yer alır. Serumda 39-43 U/mL gibi değerlerden düşük düzeyde bulunması beklenir. CA19-9 bazı kanser türlerinde yüksek düzeyde bulunabilmektedir. Her olguda CA19-9 düzeyi yükselmemektedir, bu nedenle kanser taramalarında önerilmemekte, daha çok hastaların takibinde kullanılmaktadır. Kolorektal karsinomların yanı sıra pankreas, hepatobiliyer sistem ve gastrointestinal sistem kanserlerinin tanılarında, tedaviye yanıtın takibinde ve tedavi olmuş olgulardaki nüksün erken saptanmasında kullanılmaktadır. Kolorektal karsinom olgularının \%156o’ında, pankreas karsinomlarının \%70-95’inde, diğer kanserlerde de farklı oranlarda CA19-9 serum düzeyi yükselmektedir. Karsinomlar dışında özellikle ülseratif kolit ve Crohn gibi bazı barsak hastalıklarında da CA19-9 yüksekliği görülebilmektedir. Lewis A ve B antijenleri üretilmeyen o kan grubu olan kişilerde CA19-9 üretimi de olmaz; bu kişilerde CA19-9 tümör belirteci olarak kullanılamamaktadır 14,21,27,32-35.

CA19-9'un kolorektal karsinomlarda tanısal ve prognostik belirteç olarak araştırıldığı raporlar mevcuttur. Lindmark ve ark. ${ }^{36}$ CA19-9 için eşik değeri 14 U/mL olarak kabul etmişler ve CA19-9'nin tanısal duyarlılığını \%58 olarak bulmuşlardır. Behbehani ve ark. ${ }^{37}$ eşik değerin $43 \mathrm{U} / \mathrm{mL}$ olarak kabul edildiği çalışmalarında 2 yıllık sağ kalım 
oranının CA19-9'un düşük olduğu hastalarda anlamlı olarak yüksek saptamışlardır. Carpelan-Holmström ve ark. ${ }^{22}$ eşik değerin $37 \mathrm{U} / \mathrm{mL}$ olarak kabul edildiği çalışmalarında lojistik regresyon analizi yapmışlar ve CA19-9'un kolorektal karsinom nüksü konusunda güvenilir bilgi sağlamadığını belirtmişlerdir. Filella ve ark.33 da eşik değerin $37 \mathrm{U} / \mathrm{mL}$ olarak kabul edildiği çalışmalarında CA19-9'un relaps konusundaki duyarlılığını \%38 gibi düşük bir oranda bulmuşlardır. Okamura ve ark.34 toplam 17 bin hastayı kapsayan meta analizlerinde CA19-9'un cerrahi sonrası kolorektal karsinom nükslerini yakalamada duyarlılık oranını \%29 olarak hesaplamışlardır. Kolorektal karsinom cerrahisi sonrası nüksleri yakalama duyarlılığı yine farklı çalışmalarda \%1780 gibi farklı oranlarda bulunmuştur. Preoperatif CA19-9 yüksekliğinde nüksü yakalama oranları CEA ile yakın bulunsa da tek başına preoperatif CA19-9 düzeyinin bakılması yeterli görülmemiş, postoperatif düzeyi ile değerlendirilmesi önerilmiştir. CA19-9 ile ilgili tüm bu veriler CA19-9'un tek başına kolorektal karsinom taramasında, tanısında, prognozunun belirlenmesinde veya nükslerin yakalanmasında kullanılamayacağını, diğer belirteçlerle birlikte kullanıldığında bilgi sağlayıcı olabileceğini göstermektedir.

Kanser Antijeni 242 (CA242): CA242 hücre yüzeyinde veya serumda çekirdek proteinlerine ya da lipidlerine bağlı halde saptanan sialik asit içeren karbonhidrat antijenidir. Tanısal amaçlı olarak başta pankreas kanseri olmak üzere kolorektal karsinomda ve diğer bazı kanserlerde kullanılmaktadır. Malign dokularda normal dokulara göre daha yüksek düzeyde bulunması CA242'ün kanser hücreleri tarafından üretildiğini düşündürmektedir35,38-41. Dou ve ark.39 yaklaşık 35 bin hastayı kapsayan meta analizlerinde başta pankreas kanseri olmak üzere 27 farklı türdeki kanser hastalarında ortanca CA242 düzeylerinin sağlıklı kontrollere göre anlamlı yüksek olduğunu bulmuşlardır. Ancak bunun tersine, beyin hasarı ve anemi olan hastalarda CA242 düzeyinin kontrollere göre anlamlı düşük olduğunu belirtmişlerdir. Bu araştırmacılar CA242'nin sadece kanser türlerinde değil, tip 2 diabetes mellitus ve koroner kalp hastalıklarında da kullanılabilecek bir belirteç olduğunu vurgulamışlardır. Wang ve ark.35 CA242'nin CEA ve CA19-9 ile birlikte kullanımının kolorektal karsinom için bağımsız prognostik faktör olduğunu rapor etmişlerdir. Wu ve ark.40 CA242'nin kolorektal karsinom saptanmasında CEA ile birlikte kullanıldığında CEA' nın tek başına kullanımına göre anlamlı yüksek duyarlılık ve doğruluk oranına sahip olduğunu 
bildirmişlerdir. Yang ve ark. ${ }^{41}$ CA242'ün kolorektal karsinomlu hastalarda evre, lenf nodu metastazı, invazyon derinliği ve genel sağ kalım oranının belirlenmesinde bağımsız bir prognostik faktör olduğunu saptamışlardır. Tüm bu veriler CA242'nin kolorektal karsinom tanısında ve prognozunun belirlenmesinde özellikle CEA ve/veya CA19-9 gibi farklı tümör belirteçleriyle birlikte kullanılabileceğini göstermektedir.

C-reaktif Proteini (CRP): CRP 120 kilodalton molekül ağırlığı olan bir akut faz proteinidir. Serum CRP düzeyi akut faz yanıtında hızlıca yükselir, 48 saat içinde binlerce kat artıp hızlıca normal düzeye inebilir. CRP’nin çok çeşitli fonksiyonları bulunmaktadır; klasik kompleman yolunu aktive eder, ölü hücreleri fagosite eder, selektinlerin ve bazı kemotaktiklerin ekspresyonunu arttırır. CRP düzeyi birçok doku hasarı gibi durumlarda ve hastalıklarda artış gösterir42-44. CRP duyarlı ancak nonspesifik bir inflamasyon belirtecidir 45 .

Tsilidis ve ark.45 yaklaşık 40 bin kişiyi kapsayan prospektif çalışmalar üzerine yaptıkları meta analizde CRP' yi kolorektal kanser gelişme riski ile zayıf ilişkili bulmuşlardır. Ek olarak, kronik kontrol dışı düşük evreli kolon inflamasyonunun kolorektal neoplazi gelişiminden sorumlu olabileceğini ve bu yüzden yüksek düzeyde duyarlı olan CRP' nin kolorektal kanser gelişimi veya progresyonu ile ilişkili olabileceğini belirtmişlerdir. Kigawa ve ark.46 da yüksek CRP düzeyleri ile kolorektal adenoma prevalansı artışı ile anlamlı ilişkili bulmuşlardır. Pathak ve ark.43 205 çalışmayı kapsayan meta analizlerinde preoperatif yüksek serum CRP düzeyleri ile evre 4 kolorektal karsinom hastalarındaki mortalite oranlarını anlamlı olarak ilişkili bulmuşlar ve CRP' nin kolorektal karsinom prognozunun belirlenmesinde kullanılabileceğini belirtmişlerdir. Tüm bu veriler CRP' nin inflamasyon için spesifik bir belirteç olduğunu, kolorektal karsinom gelişme riskini belirlemede, tanı koymada ve prognozu anlamada kullanılabileceğini ancak kolorektal karsinoma özgül bir belirteç olmadığını göstermektedir.

\section{Vasküler Endotelyal Büyüme Faktörü (VEGF)}

Vasküler Endotelyal Büyüme Faktörü endotel hücrelerine spesifik etkileri olan çok fonksiyonlu bir büyüme faktörü grubudur. Trombosit Kaynaklı Büyüme Faktörü (PDGF) süper ailesinin bir üyesi olup VEGF A-E ve Plasenta Büyüme Faktörü (PIGF) denilen üyelerden oluşmaktadır. VEGF endotel hücrelerinin proliferasyonu, 
migrasyonu ve diferansiasyonunda rol oynar. Ayrıca angiogenez için ve yara iyileşmesi, tümör büyümesi, embriyogenez ve bazı inflamatuvar hastalıklar gibi endotel hücrelerinin rol oynadığı çeşitli fonksiyonlar için gereklidir. VEGF polimorfizmlerinin kolorektal kansere duyarlılık ile ilişkili olduğu belirtilmiştir47-51. Zhou ve ark.48 yaptıkları meta analizde VEGF ile kolorektal karsinom ilişkisini göstermişlerdir. Aynı şekilde, Watson ve ark.49 ve Bae ve ark.50 da VEGF ile kolorektal kanseri ilişkili bulmuşlardır. Wang ve ark. ${ }^{11}$ ise yaptıkları meta analizde VEGF düzeylerinin kolorektal karsinom uzak metastazlarında 4 kattan fazla bir artış gösterdiğini belirtmişler ve VEGF düzeylerinin kolorektal karsinomlu hastalar için prognostik bir belirteç olarak kullanılabileceğini vurgulamışlardır. Tüm bu veriler VEGF ile kolorektal karsinom ilişkisini göstermekte ve VEGF' in bu olgularda tanıda ve prognozu belirlemede belirteç olarak kullanılabileceğini ortaya koymaktadır.

MicroRNA'lar: MicroRNA'lar 18-24 nükleotid uzunluğunda korunmuş endojen, RNA kodlamayan gruplardır. MicroRNA'lar öncelikle hedef RNA'nın translasyona uğramamış üç ucuna bağlanarak yaptığı posttranskripsiyonel süreç üzerinden gen ekspresyonunu regüle eder ve bu mRNA degredasyonuna ve/veya translasyonel represyonuna yol açar. Tümör süpresör genleri hedefleyen microRNA'lar (onkomiR'ler) bulunmuştur. $\mathrm{Bu}$ yapılarda değişimler olabildiği görülmüştür. Bu değişimlerin hücre proliferasyonunu indüklediği, apoptoza ve kemoterapiye direnci arttırdığı ve metastazı başlattığı bildirilmiştir. Birçok microRNA' nın ekspresyonunun normal kolon dokusu ile kolorektal karsinom arasında anlamlı farklılık gösterdiği saptanmıştır7,8,52,53.

Yau ve ark.52 microRNA' lar ile ilgili yaptıkları meta analizde microRNA' ların genel olarak kolorektal kanser tanısında duyarlılı̆̆ının \%58,8, özgüllüğünün ise \%84,8 olduğunu hesaplamışlardır. Bu araştırmacılar en güvenilir sonuç veren microRNA' nın \%59,3 duyarlılı ve \%85,6 özgüllük oranlarıyla microRNA-21 olduğunu rapor etmişlerdir. Ek olarak microRNA-21 ve microRNA-92a'nın ve kombinasyon halinde kullanımlarının fekal temelli kolorektal kanser taramasında umut verici biyobelirteçler olduğu sonucuna varmışlardır. Peng ve ark.7 ise microRNA-92a' nın kolorektal karsinom riskinin, nüksün ve zayıf sağ kalım oranının öngörülmesinde umut verici olduğunu belirtmişlerdir. Wei ve ark. ${ }^{8}$ microRNA-124’ün kolorektal karsinom için bağımsız bir prognostik faktör olduğunu bildirmişlerdir. Guraya ve ark.53 yaptıkları meta analizde microRNA-21'in güçlü bir prognostik faktör olduğu sonucuna 
varmışlardır. Bu veriler microRNA'ların kolorektal karsinom taramasında, tanısında ve prognozunun belirlenmesinde kullanılabileceğini göstermektedir.

Diğer Biyobelirteçler: Kolorektal karsinomda tarama, tanı, izlem ya da prognozun belirlenmesi amacıyla araştırılan başka biyobelirteçler de bulunmaktadır:

Kanser Antijeni 50 (CA-50) kolorektal Colo-205 kanser hücrelerinin yüzeyinde eksprese edilen kansere özgü bir antijendir. Shan ve ark. ${ }^{44}$ yaptıkları meta analizde CA50'nin kolorektal karsinom dışında pankreas ve akciğer kanseri, siroz ve pankreatit gibi birçok hastalıkta da yükseldiğini belirtmişler ve CA50'nin bir sistem fonksiyon bozukluğu göstergesi olduğu sonucuna varmışlardır.

İnsülin Benzeri Büyüme Faktörü Bağlanma Proteini 3 (IGFBP-3) hücre proliferasyonunu başlatan ve apoptozu inhibe eden, bu nedenle karsinogenezde rol oynayan İnsülin Benzeri Büyüme Faktörü-1’i (IGF-1) antagonize eder55. Yoon ve ark.55 yaptıkları meta analizde IGF-1 ve IGFBP-3'ün ve bunların birbirlerine oranlarının kolorektal karsinomun ortaya çıkması riski ile ilişkili olmadığı sonucuna varmışlar, ancak IGF-1'in ileri evre kanser riskindeki artış ile ilişkili olduğunu bulmuşlardır.

Kanser Antijeni 72-4'ün (CA72-4) kolorektal kanser tanısında duyarlılığının \%50, özgüllüğünün \%86 olduğu yapılan bir meta analizde gösterilmiş ve kanser taramasında sınırlı performansı olan bir belirteç olduğu belirtilmiştir56.

Tümör İlişkili Glikoprotein-72 (TAG-72) birçok karsinomda aşırı eksprese edilen bir membrana bağlı glikoprotein kompleksidir. TAG-72'nin kolorektal karsinomun ilerlemesinde rol oynayabilen bir faktör olduğu ve bu olgularda potansiyel terapötik bir hedef olarak düşünülebileceği belirtilmiştir ${ }^{57}$.

P53 bir tümör supresör proteinidir ve sınırlı sayıdaki çalışmalara rağmen P53’e karşı oluşmuş antikor pozitifliği olanların kolorektal karsinom gelişme riskinin daha yüksek olduğu ve $\mathrm{P}_{53}$ 'ün kolorektal karsinom erken tanısında kullanılabileceği bildirilmiştir58. Kanser Antijeni 125’in (CA125) CEA, CA19-9 ve CA72-4 gibi diğer belirteçlerle birlikte kullanımının kolorektal karsinom tanısında ve prognozunda kullanılabileceği belirtilmiştir59. CerbB-2 proteininin kolorektal karsinom prognozunda belirleyici olmadığı bildirilmiştir6o.

Doku Metalloproteinaz İnhibitörü-1’in (TIMP-1) kolorektal karsinom tanısında \%65 
duyarlılık ve \%87 özgüllüğe sahip olduğu ve bu olguların taranmasında kullanılabileceği belirtilmiştir ${ }^{61}$.

Pirüvat Kinaz İzoenzimi M2'nin (M2-PK) kolorektal karsinom taramasında duyarlılık oranının \%79, özgüllük oranının ise \%80 olduğu ve tarama amaçlı olarak kullanılabileceği rapor edilmiştir ${ }^{62}$.

\section{Sonuç ve Öneriler}

Kolorektal karsinomların taranmasında, tanısında, izleminde ve prognozunun belirlenmesinde ileri derecede güvenilir bir biyobelirteç henüz belirlenebilmiş değildir. Ancak belirteçlerin araştırılması değişik duyarlılık ve özgüllük oranlarına rağmen klinisyene ve hasta için büyük fayda sağlamaktadır. Özellikle bazı belirteçlerin kombine kullanımının bu olgularda önemli yarar sağladığı görülmüştür.

\section{KAYNAKLAR}

1. Liu Z, Zhang Y, Niu Y, et al. A systematic review and meta-analysis of diagnostic and prognostic serum biomarkers of colorectal cancer. Plos One. 2014;9(8):e103910. doi: 10.1371/journal.pone.0103910.

2. Duffy MJ, van Dalen A, Haglund C, et al. Tumour markers in colorectal cancer: European Group on Tumour Markers (EGTM) guidelines for clinical use. European Journal of Cancer. 2007;43(9):1348-60.

3. Bray C, Bell LN, Liang H, Collins D, Yale SH. Colorectal cancer screening. Wisconsin Medical Journal. 2017;116(1):27-33.

4. Duffy MJ. Carcinoembryonic antigen as a marker for colorectal cancer: Is it clinically useful? Clinical Chemistry. 2001;47(4):624-30.

5. Issa IA, Noureddine M. Colorectal cancer screening: An updated review of the available options. World Journal of Gastroenterolgy . 2017;23(28):5086-5096. doi: 10.3748/wjg.v23.i28.5086.

6. Onyoh EF, Hsu WF, Chang LC, Lee YC, Wu MS, Chiu HM. The rise of colorectal cancer in Asia: epidemiology, screening, and management. Current Gastroenterology Reports. 2019;21(8):36. doi: 10.1007/s11894-019-0703-8. 
7. Peng Q, Shen Y, Lin K, Zou L, Shen Y, Zhu Y. Identification of microRNA-92a and the related combination biomarkers as promising substrates in predicting risk, recurrence and poor survival of colorectal cancer. Journal of Cancer. 2019;10(14):3154-3171. doi: 10.7150/jca.30306.

8. Wei C, Lei L, Hui H, Tao Z. MicroRNA-124 regulates TRAF6 expression and functions as an independent prognostic factor in colorectal cancer. Oncology Letters. 2019;18(1):856-863. doi: 10.3892/ol.2019.10358.

9. Goldstein MJ, Mitchell EP. Carcinoembryonic antigen in the staging and follow-up of patients with colorectal cancer. Cancer Investigation. 2005;23(4):338-51.

10. Fernandes LC, Kim SB, Matos D. Cytokeratins and carcinoembryonic antigen in diagnosis, staging and prognosis of colorectal adenocarcinoma. World Journal of Gastroenterology. 2005;11(5):645-8.

11. Fletcher RH. Carcinoembryonic antigen. Annals of Internal Medicine, 1986;104:66-73.

12. Klapdor R, Aronsson A-C, Du $\square$ y MJ, et al. Tumor markers in gastrointestinal cancers: European Group on Tumour Markers (EGTM) recommendations. Anticancer Research. 1999;119:2811-2815.

13. Duffy MJ, van Dalen A, Haglund C, et al. Clinical utility of biochemical markers in colorectal cancer: European Group on Tumour Markers (EGTM) guidelines. European Journal of Cancer. 2003;39(6):718-27.

14. Duffy MJ. CA 19-9 as a marker for gastrointestinal cancers: a review. Annals of Clinical Biochemistry. 1998;35(3):364-70.

15. Midgley R, Kerr D. Colorectal cancer. Lancet. 1999;353:391-9.

16. Wild N, Andres $\mathrm{H}$, Rollinger W, et al. A combination of serum markers for the early detection of colorectal cancer. Clinical Cancer Research. 2015;16(24):6111-21. doi: 10.1158/1078-0432.CCR-10-0119.

17. Lee H, Rhee H, Kang HJ, et al. Macrophage migration inhibitory factor may be used as an early diagnostic marker in colorectal carcinomas. America Journal of Clinical Pathology. 2008;129(5):772-9. doi: 10.1309/GFCLLRH8A68XKMJN. 
18. Saito N, Kameoka S. Serum laminin is an independent prognostic factor in colorectal cancer. International Journal of Colorectal Dissease. 2005;20(3):23844.

19. Marrelli D, Caruso S, Neri A, et al. Clinical utility of serum tumor markers in the diagnosis of malignant intestinal occlusion. A prospective observational study. The International Journal of Biological Markers. 2011;26(1):58-64.

20. Dbouk HA, Tawil A, Nasr F, Kandakarjian L, Abou-Merhi R. Significance of CEA and VEGF as diagnostic markers of colorectal cancer in Lebanese patients. The Open Clinical Cancer Journal. 2007;8(1):1-5. doi: 10.2174/1874189400701010001.

21. Chen JS, Chou YP, Chen KT, et al. Detection of annexin A autoantibodies in sera from colorectal cancer patients. Journal of Clinical Gastroenterology. 2011;45(2):125-32. doi: 10.1097/MCG.obo13e3181e88oee.

22. Takeda A, Otani Y, Iseki H, et al. Clinical significance of large tenascin-C spliced variant as a potential biomarker for colorectal cancer. World Journal of Surgery. 2007;31(2):388-94.

23. Coban S, Ozkan H, Köklü S, et al. The utility of serum receptor-binding cancer antigen expressed on SiSo cells in gastrointestinal tract cancers. Canadian Journal of Gastroenterology. 2006;20(9):593-6. doi: 10.1155/2006/276247

24. Bast RC Jr, Ravdin P, Hayes DF, et al. American Society of Clinical Oncology Tumor Markers Expert Panel. 2000 update of recommendations for the use of tumor markers in breast and colorectal cancer: clinical practice guidelines of the American Society of Clinical Oncology. Journal of Clinical Oncology. 2001;19(6):1865-78.

25. Grem J. The prognostic importance of tumor markers in adenocarcinomas of the gastrointestinal tract. Current Opinion in Oncology . 1997;9(4):380-7.

26. Huo YR, Glenn D, Liauw W, Power M, Zhao J, Morris DL. Evaluation of carcinoembryonic antigen (CEA) density as a prognostic factor for percutaneous ablation of pulmonary colorectal metastases. European Radiology. 2017;27(1):128137. 
27. Peltonen R, Österlund P, Lempinen M, Nordin A, Stenman UH, Isoniemi H. Postoperative CEA is a better prognostic marker than CA19-9, hCG $\beta$ or TATI after resection of colorectal liver metastases. Tumour Biology. 2018;40(1):1-9. doi: $10.1177 / 1010428317752944$.

28. Yang KM, Park IJ, Kim CW, Roh SA, Cho DH, Kim JC. The prognostic significance and treatment modality for elevated pre- and postoperative serum CEA in colorectal cancer patients. Annals of Surgical Treatment and Research. 2016;91(4):165-171.

29. Park IJ, Choi GS, Lim KH, Kang BM, Jun SH. Serum carcinoembryonic antigen monitoring after curative resection for colorectal cancer: clinical significance of the preoperative level. Annals of Surgical Oncology . 2009;16(11):3087-93. doi: 10.1245/s10434-009-0625-Z.

30. Louhimo J, Carpelan HM, Alfthan H, Stenman UH, Järvinen HJ, Haglund C. Serum HCG beta, CA 72-4 and CEA are independent prognostic factors in colorectal cancer. International Journal of Cancer. 2002;101(6):545-8.

31. Carriquiry LA, Pineyro A. Should carcinoembryonic antigen be used in the management of patients with colorectal cancer. Dissease of Colon Rectum. 1999;42:921-9.

32. Carpelan HM, Louhimo J, Stenman UH, Alfthan H, Haglund C. CEA, CA 19-9 and CA 72-4 improve the diagnostic accuracy in gastrointestinal cancers. Anticancer Research. 2002;22(4):2311-6.

33. Nakayama T, Watanabe M, Teramoto T, Kitajima M. CA19-9 as a predictor of recurrence in patients with colorectal cancer. Journal of Surgical Oncology. 1997;66(4):238-43.

34. Okamura R, Hasegawa S, Hida K, et al. Japanese study group for postoperative follow-up of colorectal cancer. The role of periodic serum CA19-9 test in surveillance after colorectal cancer surgery. International Journal of Clinical Oncology. 2017;22(1):96-101. doi: 10.1007/s10147-016-1027-4.

35. Wang J, Wang X, Yu F, et al. Combined detection of preoperative serum CEA, 
CA19-9 and CA242 improve prognostic prediction of surgically treated colorectal cancer patients. International Journal of Clinical and Experimental Pathology. 2015;8(11):14853-63.

36. Lindmark G, Bergström R, Påhlman L, Glimelius B. The association of preoperative serum tumour markers with Dukes' stage and survival in colorectal cancer. British Journal of Cancer. 1995;71(5):1090-4.

37. Behbehani AI, Al-Sayer H, Farghaly M, et al. Prognostic significance of CEA and CA 19-9 in colorectal cancer in Kuwait. International Journal of Biological Markers. 2000;15(1):51-5.

38. Filella X, Molina R, Piqué JM, et al. Use of CA 19-9 in the early detection of recurrences in colorectal cancer: comparison with CEA. Tumour Biology. 1994;15(1):1-6.

39. Dou H, Sun G, Zhang L. CA242 as a biomarker for pancreatic cancer and other diseases. Progress in Molecular Biology and Translational Science. 2019;162:229239. doi: 10.1016/bs.pmbts.2018.12.007.

40. Wu J, Yu H, Shao Y. Significance of CEA and CA242 in the diagnosis of colorectalcarcinoma. Zhonghua Zhong Liu Za Zhi. 1995;17(6):438-40.

41. Yang XQ, Chen C, Hou JX, Peng CW, Huang CQ, Li Y. Preoperative serum carbohydrate antigen 242 is a useful predictive and prognostic marker in colorectal cancer. Hepatogastroenterology. 2011;58(106):377-82.

42. Pathak A, Agrawal A. Evolution of C-Reactive Protein. Front Immunology. 2019;30(10):943. doi: 10.3389/fimmu.2019.00943.

43. Pathak S, Nunes QM, Daniels IR, Smart NJ. Is C-reactive protein useful in prognostication for colorectalcancer? A systematic review. Colorectal Dissease. 2014;16(10):769-76. doi: 10.1111/codi.12700.

44. Wu Y, Potempa LA, El Kebir D, Filep JG. C-reactive protein and inflammation: conformational changes affect function. Biological Chemistry. 2015;396(11):118197. doi: 10.1515/hsz-2015-0149.

45. Tsilidis KK, Branchini C, Guallar E, Helzlsouer KJ, Erlinger TP, Platz EA. C- 
reactive protein and colorectal cancer risk: a systematic review of prospective studies. International Journal of Cancer. 2008;123(5):1133-40. doi: 10.1002/ijc.236o6.

46. Kigawa N, Budhathoki S, Yamaji T, Iwasaki M, Inoue M, Tsugane S. Association of plasma C-reactive protein level with the prevalence of colorectal adenoma: the colorectal adenoma study in Tokyo. Scientific Reports. 2017;7(1):4456. doi: 10.1038/s41598-017-04780-9.

47. Uccelli A, Wolff T, Valente P, et al. Vascular endothelial growth factor biology for regenerative angiogenesis. Swiss Medical Weekly. 2019;149:w20011. doi: 10.4414/smw.2019.20011.

48. Zhou LP, Luan H, Dong XH, Jin GJ, Man DL, Shang H. Vascular endothelial growth factor gene polymorphisms and colorectal cancer risk: a meta-analysis. Genetics and Molecular Research. 2011;10(4):3674-88. doi: 10.4238/2011.October.31.13.

49. Watson CJ, Webb NJ, Bottomley MJ, Brenchley PE. Identification of polymorphisms within the vascular endothelial growth factor (VEGF) gene: correlation with variation in VEGF protein production. Cytokine. 2000;12:12321235 .

50. Bae SJ, Kim JW, Kang H, et al. Gender-specific association between polymorphism of vascular endothelial growth factor (VEGF $936 \mathrm{C}>\mathrm{T}$ ) gene and colon cancer in Korea. Anticancer Res. 2008;28:1271-1276.

51. Wang Y, Yao X, Ge J, Hu F, Zhao Y. Can vascular endothelial growth factor and microvessel density be used as prognostic biomarkers for colorectal cancer? A systematic review and meta-analysis. Scientific World Journal. 2014;2014:1-13. doi: 10.1155/2014/102736.

52. Yau TO, Tang CM, Harriss EK, Dickins B, Polytarchou C. Faecal microRNAs as a non-invasive tool in the diagnosis of colonic adenomas and colorectal cancer: A meta-analysis. Scientific Reports. 2019;9(1):1-13. doi: 10.1038/s41598-019-455709. 
53. Guraya S. Prognostic significance of circulating microRNA-21 expression in esophageal, pancreatic and colorectal cancers; a systematic review and metaanalysis. Int J Surg. 2018;60:41-47. doi: 10.1016/j.ijsu.2018.10.030.

54. Shan M, Tian Q, Zhang L. Serum CA50 levels in patients with cancers and other diseases. Progress in Molecular Biology and Translational Science. 2019;162:187198. doi: 10.1016/bs.pmbts.2018.12.006.

55. Yoon YS, Keum N, Zhang X, Cho E, Giovannucci EL. Circulating levels of IGF-1, IGFBP-3, and IGF-1/IGFBP-3 molar ratio and colorectal adenomas: A metaanalysis. Cancer Epidemiology. 2015;39(6):1026-35. doi: 10.1016/j.canep.2015.09.004.

56. Yanqing H, Cheng D, Ling X. Serum CA72-4 as a Biomarker in the diagnosis of colorectal cancer: A meta-analysis. Open Med (Wars). 2018;13:164-171. doi: 10.1515/med-2018-0026.

57. Cho J, Kim KM, Kim HC, et al. The prognostic role of tumor associated glycoprotein 72 (TAG-72) in stage II and III colorectal adenocarcinoma. Pathol Res Pract. 2019;215(1):171-176. doi: 10.1016/j.prp.2018.10.024.

58. Teras LR, Gapstur SM, Maliniak ML, et al. Prediagnostic antibodies to serum p53 and subsequent colorectal cancer. Cancer Epidemiol Biomarkers Prev. 2018;27(2):219-223. doi: 10.1158/1055-9965.EPI-17-0407.

59. Gao Y, Wang J, Zhou Y, Sheng S, Qian SY, Huo X. Evaluation of serum CEA, CA199, CA72-4, CA125 and ferritin as diagnostic markers and factors of clinical parameters for colorectal cancer. Sci Rep. 2018;8(1):2732. doi: 10.1038/s41598018-21048-y.

60. McKay JA, Loane JF, Ross VG, et al. c-erbB-2 is not a major factor in the development of colorectal cancer. Br J Cancer. 2002;86(4):568-73.

61. Meng C, Yin X, Liu J, Tang K, Tang H, Liao J. TIMP-1 is a novel serum biomarker for the diagnosis of colorectal cancer: A meta-analysis. PLoS One. 2018;13(11):e0207039. doi: 10.1371/journal.pone.0207039. 
62. Uppara M, Adaba F, Askari A, et al. A systematic review and meta-analysis of the diagnostic accuracy of pyruvate kinase M2 isoenzymatic assay in diagnosing colorectal cancer. World J Surg Oncol. 2015;13:48-56. doi: 10.1186/s12957-0150446-4. 